\title{
EVALUATION OF THE SELECTIVITY AND EFFICIENCY OF SYNTHETIC SEX PHEROMONES OF LEAF-ROLLERS FROM DIFFERENT MANUFACTURERS
}

\author{
Žaneta Pražanová ${ }^{1}$, Hana Šefrová ${ }^{1}$ \\ ${ }^{1}$ Department of Crop Science, Breeding and Plant Medicine, Faculty of AgriSciences, Mendel University in Brno, \\ Zemědělská 1, 61300 Brno, Czech Republic
}

Link to this article: https://doi.org/10.11118/actaun.2021.014

Received: 7. 9. 2020, Accepted: 28. 1. 2021

To cite this article: PRAŽANOVÁ ŽANETA, ŠEFROVÁ HANA. 2021. Evaluation of the Selectivity and Efficiency of Synthetic Sex Pheromones of Leaf-Rollers from Different Manufacturers. Acta Universitatis Agriculturae et Silviculturae Mendelianae Brunensis, 69(1): 139-147.

\begin{abstract}
In 2019 (May-September), the efficiency of pheromone lures for Grapholita funebrana Treitschke, 1835 and Pandemis heparana (Denis \& Schiffermüller, 1775) from two manufacturers (Propher, Pherobank) were compared. Monitoring was performed in three study areas in South Moravia (Czech Republic): Kyjov (faunistic square 6968), Brno-Soběšice (6765) and Brno-Starý Lískovec (6865). A total of 14 pheromone traps, from both companies, were suspended. Both target species were found in the traps, with Grapholita funebrana present in all study areas (a total of 5107 adults) and Pandemis heparana was found in Kyjov (64 adults). Furthermore, 2061 individuals of non-target species from the Autostichidae, Noctuidae, Tortricidae and Yponomeutidae families were captured. And 7 non-target species were captured using the pheromone for G. funebrana, most numerously Grapholita molesta (Busck, 1916), Cnephasia stephensiana (Doubleday, 1849) and Argyresthia trifasciata Staudinger, 1871; while, only two non-target species were identified using the pheromone for P. heparana, Noctua fimbriata (Schreber, 1759) and Yponomeuta malinellus Zeller, 1838. Compared to Propher pheromones, Pherobank pheromones were more attractive for target species and less attractive for non-target species.
\end{abstract}

Keywords: pheromone lures, pheromone traps, Grapholita funebrana, Pandemis heparana, non-target species

\section{INTRODUCTION}

The chemical composition of pheromones in many insect species is currently known, for example the Dutch company Pherobank offers pheromone lures for more than 500 species (Pherobank, 2020). Synthetic sex pheromones make it possible to determine the number of adults (individuals) (in practice they are mainly used to monitor abundance of pests, especially species from the families: Tortricidae, Sesiidae, Crambidae and Pyralidae), and also help determine the time of occurrence for the most accurate timing of the plant control.
Leaf-rollers are among the most widespread and diverse Lepidoptera family (e.g. Scoble, 1995), with over 11,000 species known worldwide (Gilligan et al., 2018); in the Czech Republic, it is the largest of the Lepidoptera families, where Laštůvka and Liška (2011) state there are 476 species. Leaf-roller caterpillars are widespread and a serious pest in agriculture, forestry and ornamental plants, e.g. caterpillars of more species directly develop in the fruits and they distinctly reduce yield of fruit trees (Šefrová, 2014). 
In the Czech Republic, several authors paid attention to the monitoring of abundance and seasonal dynamics using synthetic sex pheromones, such as Hrdý et al. (1979, 1989, 1993, 1994, 1997), Hrudová (2003, 2005), Hluchý (2011) and Jakubíková et al. (2016), by testing lures not only on Grapholita funebrana and Pandemis heparana, but also on Grapholita molesta, G. janthinana, G. lobarzewskii, Cydia pomonella and bud (Spilonota ocellana, Hedya nubiferana) and peel leaf-rollers (Adoxophyes orana). In Hungary, these experiments were performed by Sziráki (1978) on the Grapholita molesta pheromone, and on the pheromones for $G$. funebrana and G. molesta in Bulgaria by Velcheva (2000). Later, attention was paid to non-target species.

Using various types of traps, individual authors used lures that they either produced themselves or obtained from manufacturers from several countries (Czech Republic, Hungary, Netherlands).

\section{MATERIALS AND METHODS}

\section{Study Areas}

Monitoring was carried out in the 2019 season from May to September on three study areas in the South Moravian Region in the Czech Republic. Pheromone traps were installed in an old apple orchard in Brno-Soběšice - U Jezírka, in a plum orchard in Brno-Starý Lískovec and in an apricot orchard in Kyjov (Fig. 1).

The apple orchard in U Jezírka is located in the district of Brno-City, on the northern outskirts of the city $\left(49^{\circ} 16^{\prime} 9.640^{\prime \prime} \mathrm{N}, 16^{\circ} 37^{\prime} 47.925^{\prime \prime} \mathrm{E}\right.$, faunistic square 6765). The total area of the orchard is $1.2 \mathrm{ha}$, at an altitude of $390 \mathrm{~m}$. The apple trees in the orchard are not chemically treated. There are mixed forests around the area.

The plum orchard in Starý Lískovec falls in Starý Lískovec's fruit-growing cooperative. The cooperative is located in the district of Brno-City, on the southern outskirts of the city $\left(49^{\circ} 09^{\prime} 31.4^{\prime \prime} \mathrm{N}\right.$, $16^{\circ} 34^{\prime} 25.1$ ”E, faunistic square: 6865). The total area of the orchard is $2 \mathrm{ha}$, at an altitude of $237 \mathrm{~m}$. A protective intervention against sawflies was carried out here. Around the orchard are shrubs of various species and a large apple orchard.

The apricot orchard in Kyjov is located in the district of Hodonín, on the eastern outskirts of the city $\left(49^{\circ} 00^{\prime} 33.3^{\prime} \mathrm{N}, 1^{\circ} 08^{\prime} 29.5^{\prime} \mathrm{E}\right.$, faunistic square: 6968). The total area of the orchard is 1.8 ha, with

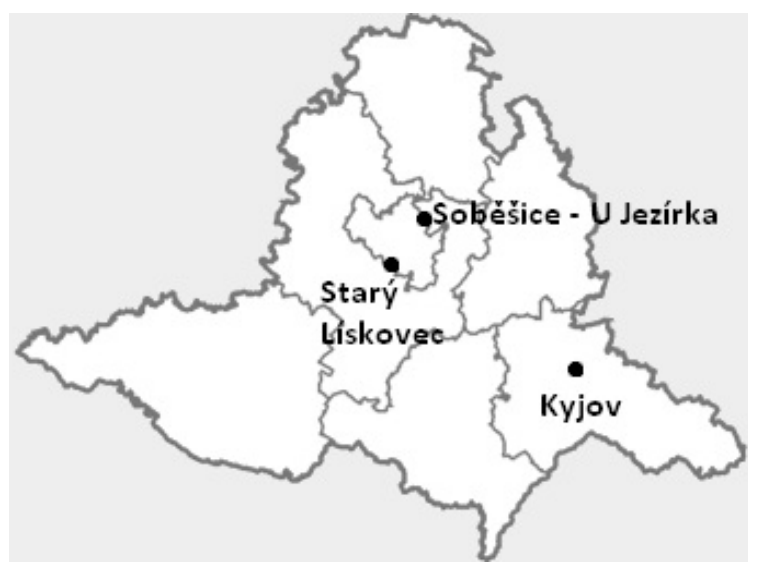

1: The location of the study areas on a map of the South Moravian Region

an altitude of $192 \mathrm{~m}$. No chemical intervention was carried out on the orchard. To a lesser extent, there are also apple, plum and walnut trees in the orchard.

\section{Pheromone Traps and Lures}

Pheromone traps and synthetic sex pheromones (pheromone lures) were purchased from Pherobank (NL) and Propher (CZ). Green (Propher) and transparent (Pherobank) plastic pheromone traps of the delta type with four types of pheromone lures (Fig. 2) were used for monitoring. A lure from Propher was used for the Grapholita funebrana species (Březová near Zlín, Czech Republic) with the active substances: (E)-dodec-8-en-1-yl acetate (0.0012 g/kg), (Z)-dodec-8-en-1-ol (0.0204 g/kg), Chemstop Ecofix (20-25\%) and dodecyl acetate $(0.2784 \mathrm{~g} / \mathrm{kg})$. A lure that was supplied by Pherobank (from the Netherlands) was used as the second lure to monitor this species. Pheromone lures for the given pest differ in the mutual ratio of active substances, which is a trade secret of the company. Pheromones from Propher and Pherobank were also used to monitor Pandemis heparana, but neither company has published the composition of this pheromone.

The pheromone for Pandemis heparana was applied only in green traps on the study area in Kyjov (June-August). A total of 14 pheromone traps were suspended (Tab. I). Four pheromone traps were applied in the study areas in Soběšice and Starý Lískovec. Six pheromone traps were applied in the study area in Kyjov.

I: Suspended pheromone traps in individual localities

\begin{tabular}{l|lllll}
\hline & \multicolumn{2}{c}{ Green traps (Propher) } & & \multicolumn{2}{c}{ Transparent traps (Pherobank) } \\
\hline Soběšice & GF Pherobank & GF Propher & & GF Pherobank & GF Propher \\
Starý Lískovec & GF Pherobank & GF Propher & & GF Pherobank & GF Propher \\
\multirow{2}{*}{ Kyjov } & GF Pherobank & GF Propher & GF Pherobank & GF Propher \\
\hline
\end{tabular}




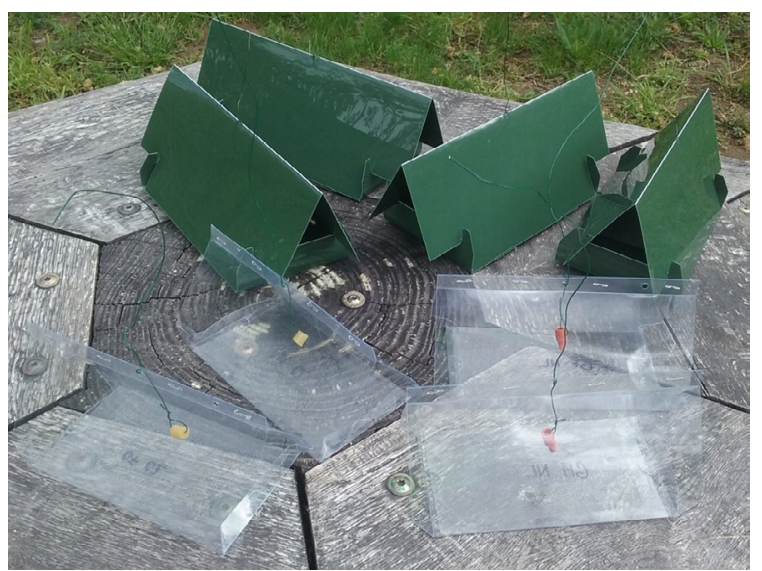

2: Green and transparent delta traps from Propher and Pherobank

The traps were suspended in May and remained in the areas until the end of September. All traps were marked to avoid confusion of the different pheromones during regular changes. Pheromones were changed after four weeks. The sticky boards were checked once a week and were changed as needed.

\section{Identification}

The determination was performed according to the morphology of genitalia (e.g. Robinson, 1976). The abdomens of adults were placed in test tubes with $10 \% \mathrm{KOH}$, where they were then boiled for 5 minutes. After cooking, the abdomens were rinsed with water and genitalia were dissected and placed in glycerol on a Petri dish. Subsequently, the determination was performed according to Razowski (2001). The determination of some specimens was revised by Z. Laštůvka.

\section{RESULTS AND DISCUSSION}

\section{Grapholita funebrana Treitschke, 1835}

Grapholita funebrana (GF) was detected in all localities. This finding was expected because
Grapholita funebrana belongs to the widespread and abundant species and significant pests of stone fruits, especially plum trees. A total of 5107 adults of this species were identified (Fig. 3), with 999 adults captured in Soběšice, 1215 in Starý Lískovec and 2893 in Kyjov.

Grapholita funebrana flew more frequently on Pherobank pheromones, with a total of 3905 adults in the study areas (Fig. 3). For Propher pheromones, a total of 1202 adults of this species were recorded. Most Grapholita funebrana were captured in Kyjov using pheromones from Pherobank (2192 adults), and the lowest numbers were in Soběšice, using pheromones from Propher (189 adults). Flying into Grapholita funebrana pheromone traps in all study areas are shown in Figs. 4, 5. The graphs show two significant flight waves in all tested areas.

\section{Pandemis heparana}

\section{(Denis \& Schiffermüller, 1775)}

In 2019, Pandemis heparana was only recorded in Kyjov when using a pheromone from Pherobank. This species did not fly to the Propher pheromone. Grapholita funebrana flights to these pheromones were not recorded either. A total of 64 adults of Pandemis heparana were captured in Kyjov. Pandemis heparana was monitored in 2017 in the Arboretum of Mendel University in Brno, in the garden in Újezd u Černé Hory (Pražanová, 2018), in 2015 in the territory of the municipality of Ruda in the Vysočina region (Komínková, 2016) and in the territory of Eastern Moravia, near Zlín (Jakubíková, 2016), but always on pheromones from Propher because pheromones from Pherobank were not used. During these years, Pandemis heparana was not detected in any of the installed traps. The occurrence of Pandemis heparana in Kyjov was confirmed using a pheromone from Pherobank. In other areas, it was not possible to confirm the occurrence of the species. However, if the adults were not captured in 2017 and 2015, it could have been due to an inappropriate pheromone composition, which the observed species were not attracted to.

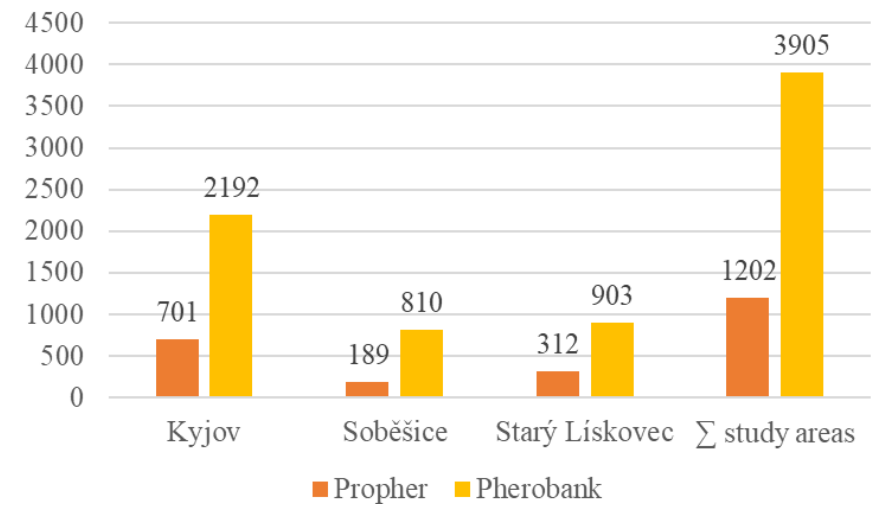

3: Number of Grapholita funebrana males captured using Propher and Pherobank pheromones 


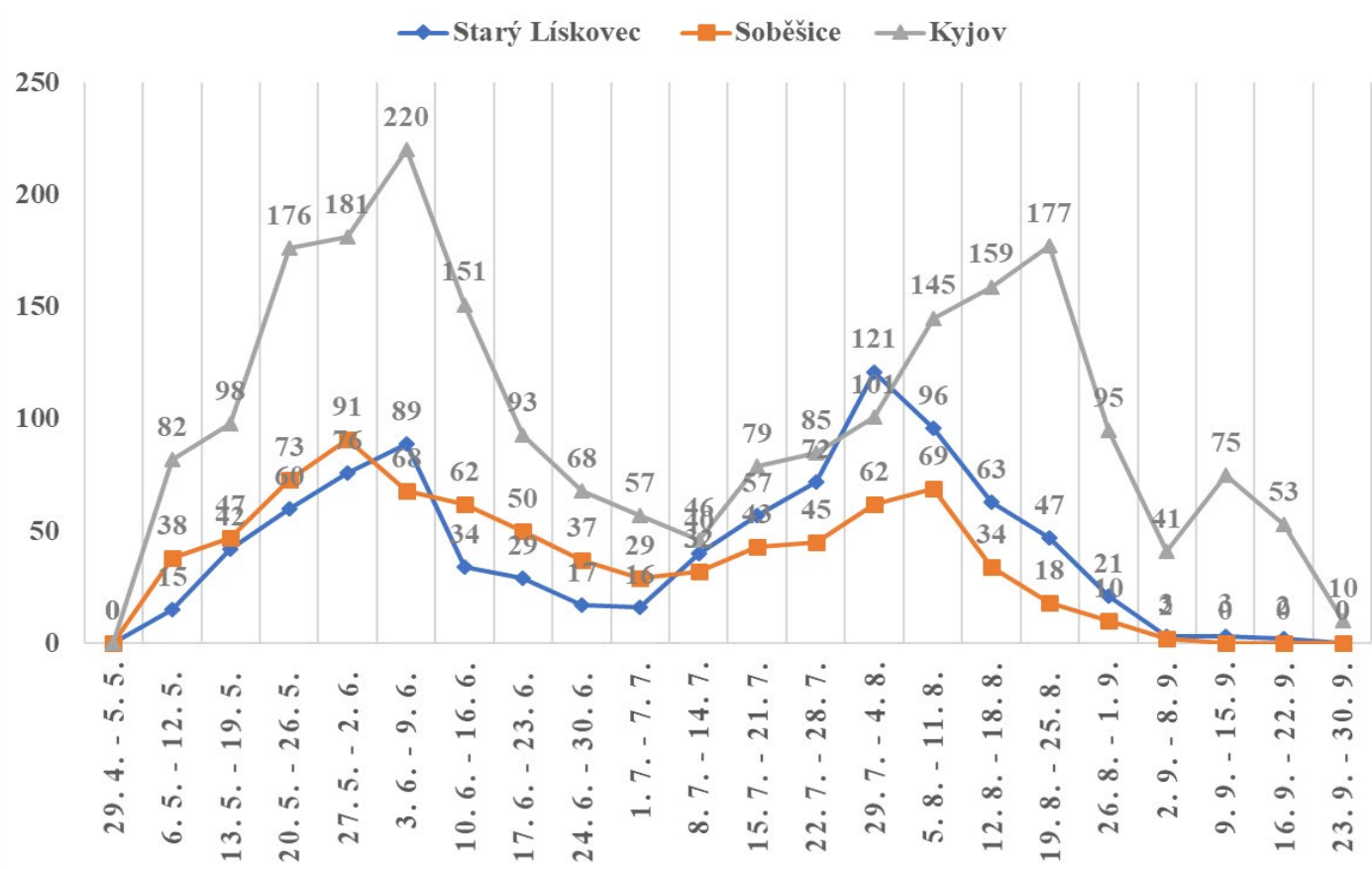

4: Flight activity of Grapholita funebrana on Pherobank GF pheromone

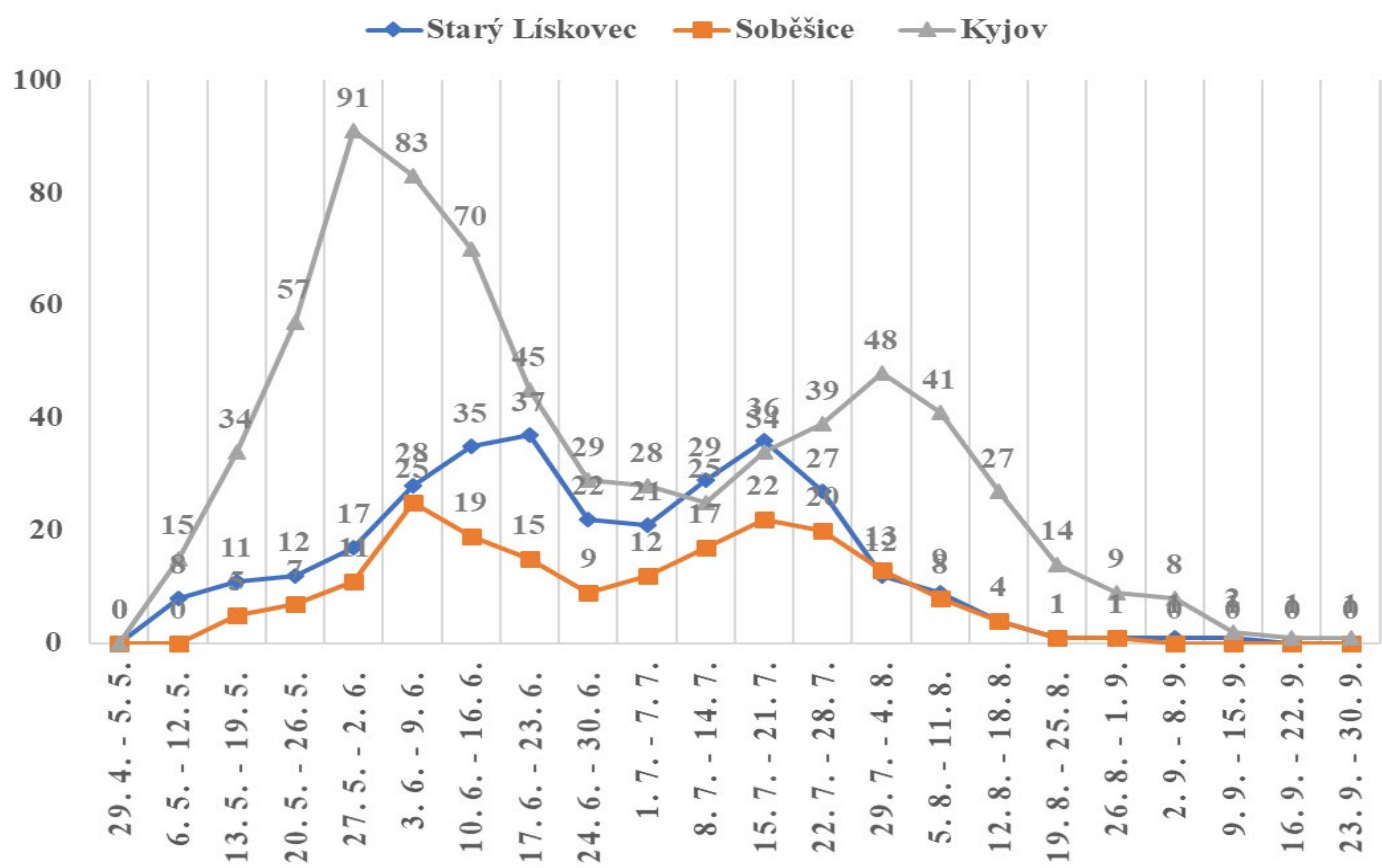

5: Flight activity of Grapholita funebrana on Propher GF pheromone

\section{Non-target Species}

A total of 2061 non-target specimens from the order Lepidoptera were recorded in the traps. A total of 668 adults of non-target species flew to Pherobank pheromones and 1393 adults of nontarget species flew to Propher pheromones. The most important non-target species captured on the Grapholita funebrana pheromones was Grapholita molesta. A total of 1702 adults of this species flew to these pheromones. Grapholita molesta, as a non- target species, was recorded at all localities and always in a trap with the pheromone GF. The specificity of sex pheromones is given by the ratio of the individual components. Grapholita funebrana and G. molesta are related species and the composition of their pheromones can be highly similar and can only differ by a small number of particles, i.e. in their ratio. Therefore, it happens that they fly into each other's traps for 'their' pheromones. Grapholita molesta more often flew to 
II: Numbers of captured non-target species in Kyjov, Soběšice and Starý Liskovec

\begin{tabular}{|c|c|c|c|c|c|c|}
\hline \multirow{3}{*}{ Locality } & \multirow{3}{*}{ Non-target species } & \multicolumn{5}{|c|}{ Pheromone } \\
\hline & & \multicolumn{2}{|c|}{ Grapholita funebrana } & \multicolumn{2}{|c|}{ Pandemis heparana } & \multirow[b]{2}{*}{$\Sigma$} \\
\hline & & Pherobank & Propher & Pherobank & Propher & \\
\hline \multirow{5}{*}{ Kyjov } & Grapholita molesta & 317 & 575 & 0 & 0 & 892 \\
\hline & Cnephasia stephensiana & 15 & 27 & 0 & 0 & 42 \\
\hline & Argyresthia trifasciata & 19 & 36 & 0 & 0 & 55 \\
\hline & Noctua pronuba & 0 & 0 & 5 & 31 & 36 \\
\hline & Yponomeuta malinellus & 0 & 0 & 4 & 9 & 13 \\
\hline \multirow{6}{*}{ Soběšice } & Grapholita molesta & 35 & 62 & 0 & 0 & 97 \\
\hline & Cnephasia stephensiana & 21 & 32 & 0 & 0 & 53 \\
\hline & Epiblema cirsiana & 0 & 15 & 0 & 0 & 15 \\
\hline & Pammene suspectana & 0 & 8 & 0 & 0 & 8 \\
\hline & Oegoconia novimundi & 4 & 23 & 0 & 0 & 27 \\
\hline & Yponomeuta malinellus & 2 & 7 & 0 & 0 & 9 \\
\hline \multirow{5}{*}{ Starý Lískovec } & Grapholita molesta & 216 & 497 & 0 & 0 & 713 \\
\hline & Cnephasia stephensiana & 13 & 29 & 0 & 0 & 42 \\
\hline & Epiblema cirsiana & 0 & 17 & 0 & 0 & 17 \\
\hline & Argyresthia trifasciata & 17 & 25 & 0 & 0 & 42 \\
\hline & $\Sigma$ & 659 & 1353 & 9 & 40 & 2061 \\
\hline
\end{tabular}

III: Non-target species registered by various authors on the Grapholita funebrana pheromone

\begin{tabular}{ll}
\hline \multicolumn{1}{c}{ Non-target species } & \\
\hline Acleris holmiana (Linnaeus, 1758) & Velcheva, 2000 \\
Acleris rhombana (Denis \& Schiffermüller, 1775) & Velcheva, 2000 \\
\hline Acronicta psi (Linnaeus, 1758) & Jakubíková et al., 2016 \\
Acronicta rumicis (Linnaeus, 1758) & Jakubíková et al., 2016 \\
Agrotis segetum (Denis \& Schiffermüller, 1775) & Hrudová, 2005 \\
Agrotis clavis (Hufnagel, 1766) & Hrdý et al., 1979 \\
Alcis repandata (Linnaeus, 1758) & Jakubíková et al., 2016 \\
Anarsia lineatella (Zeller, 1839) & Hrdý et al., 1979 \\
Apotomis infida (Heinrich, 1926) & Velcheva, 2000 \\
Argyresthia trifasciata (Staudinger, 1871) & Pražanová, 2018 \\
Celypha rosaceana (Schläger, 1847) & Jakubíková et al., 2016 \\
Celypha striana (Denis \& Schiffermüller, 1775) & Hrdý et al. 1979; Hrdý et al. 1993; Hrudová 2005; Jakubíková et al., 2016 \\
Cnephasia communana (Herrich-Schäffer,1851) & Hluchý, 2011 \\
Cnephasia genitalana (Pierce \& Metcalfe, 1922) & Hrdý et al., 1993; Velcheva, 2000 \\
Cnephasia pasiuana (Hübner, 1799) & Hluchý, 20111 \\
Cnephasia stephensiana (Doubleday, 1849) & Hrdý et al. 1993; Velcheva, 2000; Hluchý, 2011; Jakubíková et al., 2016; \\
Cydia pomonella (Linnaeus, 1758) & Hluchý, 2011 \\
\hline
\end{tabular}

1 It was very probably Cnephasia pumicana, because Hluchý determined the Cnephasia species after Razowski (2001), which had not distinguished the taxa C. pasiuana and C. pumicana, and because C. pumicana is common and widespread species in the Czech Republic unlike the very rare C. pasiuana (J. Šumpich pers. comm.). 


\begin{tabular}{|c|c|}
\hline Non-target species & Authors \\
\hline Enarmonia formosana (Scopoli, 1763) & Hrdý et al., 1979; Hrdý et al., 1993; Velcheva, 2000; Hluchý, 2011 \\
\hline Epiblema cirsiana (Zeller, 1843) & Jakubíková et al., 2016; Pražanová, 2018 \\
\hline Epiblema costipunctana (Hawort, 1811) & Hluchý, 2011 \\
\hline Epiblema sticticana (Fabricius, 1794) & Velcheva, 2000 \\
\hline Epiblema foenella (Linnaeus, 1758) & Hrdý et al., 1979; Velcheva, 2000 \\
\hline Epiblema hepaticana (Treitschke, 1835) & Velcheva, 2000 \\
\hline Epiblema junctana (Herrich-Schäffer, 1856) & Jakubíková et al., 2016 \\
\hline Epiblema mendiculana (Treitschke, 1835) & Velcheva, 2000 \\
\hline Epiblema scutulana (Denis \& Schiffermüller, 1775) & Hrdý et al., 1979; Hrdý et al., 1993; Velcheva, 2000; Hrudová, 2005 \\
\hline Euxoa nigricans (Linnaeus, 1761) & Hrdý et al., 1979 \\
\hline Grapholita coronillana (Lienig \& Zeller, 1846) & Hrudová, 2005 \\
\hline Grapholita janthinana (Duponchel, 1835) & Velcheva, 2000; Hluchý, 2011; Jakubíková et al., 2016 \\
\hline Grapholita molesta (Busck, 1916) & $\begin{array}{l}\text { Hrdý et al., 1979; Velcheva, 2000; Hrudová, 2005; Hluchý, 2011; } \\
\text { Jakubíková et al., 2016; Pražanová, } 2018\end{array}$ \\
\hline Grapholita rosana (Danilevsky, 1968)? & Velcheva, 2000 \\
\hline Grapholita tenebrosana (Duponchel, 1834) & Hrdý et al., 1979; Hrdý et al., 1993; Velcheva, 2000; Hluchý, 2011 \\
\hline Hedya dimidiana (Clerck, 1759) & Hluchý, 2011 \\
\hline Hedya nubiferana (Haworth, 1811) & Velcheva, 2000 \\
\hline Hedya pruniana (Hübner, 1799) & Velcheva, 2000; Jakubíková et al., 2016 \\
\hline Hypena proboscidalis (Linnaeus, 1758) & Jakubíková et al., 2016 \\
\hline Hypena rostralis (Linnaeus, 1758) & Jakubíková et al., 2016 \\
\hline Mesoligia furuncula (Denis \& Schiffermüller, 1775) & Hrdý et al. 1979; Jakubíková et al., 2016 \\
\hline Mesapamea secalella (Remm, 1983) & Jakubíková et al., 2016 \\
\hline Notocelia incarnatana (Hübner, 1800) & Jakubíková et al., 2016 \\
\hline Notocelia roborana (Hübner, 1796) & Hrudová, 2005 \\
\hline Notocelia rosaecolana (Doubleday, 1850) & Hrudová, 2005 \\
\hline Oegoconia novimundi (Busck, 1915) & Jakubíková et al., 2016; Pražanová, 2018 \\
\hline Pammene albuginana (Guenée, 1845) & Velcheva, 2000; Jakubíková et al., 2016 \\
\hline Pammene amygdalana (Duponchel, 1842) & Hrdý et al. 1997; Velcheva, 2000; Jakubíková et al., 2016 \\
\hline Pammene argyrana (Hübner, 1799) & Velcheva, 2000; Jakubíková et al., 2016 \\
\hline Pammene aurana (Fabricius, 1775) & Hrdý et al. 1979; Hrdý et al. 1997; Jakubíková et al., 2016 \\
\hline Pammene aurita (Razowski, 1991) & Hrdý et al., 1997 \\
\hline Pammene fasciana (Linnaeus, 1761) & Hrdý et al., 1993; Velcheva, 2000 \\
\hline Pammene gallicolana (Lienig \& Zeller, 1846) & Velcheva, 2000; Hluchý, 2011; Jakubíková et al., 2016; Pražanová, 2018 \\
\hline Pammene giganteana (Peyerimhoff, 1863) & Velcheva, 2000; Hluchý, 2011 \\
\hline Pammene populana (Fabricius, 1787) & Velcheva, 2000 \\
\hline Pammene spiniana (Duponchel, 1843) & $\begin{array}{l}\text { Mayer \& McLaughlin in Hrdý et al., 1997; Velcheva, 2000; Jakubíková } \\
\text { et al., 2016; Pražanová, } 2018\end{array}$ \\
\hline Pammene splendidulana (Guenée, 1845) & Velcheva, 2000 \\
\hline Pammene suspectana (Lienig \& Zeller, 1846) & $\begin{array}{l}\text { Hrdý et al., 1979; Hrdý et al., 1997; Velcheva, 2000; Hrudová, 2005; } \\
\text { Jakubíková et al., 2016; Pražanová, } 2018\end{array}$ \\
\hline Recurvaria nanella (Denis \& Schiffermüller, 1775) & Hrdý et al., 1979 \\
\hline $\begin{array}{l}\text { Scrobipalpa atriplicella (Fischer von Röslerstamm, } \\
\text { 1841) }\end{array}$ & Hrdý et al., 1979 \\
\hline Spilonota ocellana (Denis \& Schiffermüller, 1775) & Hrudová, 2005 \\
\hline
\end{tabular}


IV: Non-target species registered by various authors on Pandemis heparana pheromone

\begin{tabular}{|c|c|}
\hline Agapeta zoegana (Linnaeus, 1767) & Jakubíková et al., 2016 \\
\hline Cnephasia stephensiana (Doubleday, 1849) & Jakubíková et al., 2016 \\
\hline Crassa unitella (Hübner, 1796) & Pražanová, 2018 \\
\hline Epiblema cirsiana (Zeller, 1843) & Jakubíková et al., 2016 \\
\hline Euspilapteryx auroguttella (Stephens, 1835) & Jakubíková et al., 2016 \\
\hline Gypsonoma minutana (Hübner, 1799) & Jakubíková et al., 2016 \\
\hline Noctua pronuba (Linnaeus, 1761) & Hrudová, 2005 \\
\hline Polia nebulosa (Hufnagel, 1766) & Jakubíková et al., 2016 \\
\hline Tortrix viridana (Linnaeus, 1758) & Pražanová, 2018 \\
\hline Yponomeuta malinellus (Zeller, 1838) & Pražanová, 2018 \\
\hline Zygaena ephialtes (Linnaeus, 1767) & Jakubíková et al., 2016 \\
\hline
\end{tabular}

the pheromone from Propher (Tab. II). Grapholita molesta occurs mainly in warmer regions (Hrdý et al., 1979a, 1994), which could be one of the reasons why this species was most abundantly recorded in Kyjov. Also, in Kyjov, there are mainly apricot and plum trees which are the main hosts of $G$. molesta. The flying of the following species on this pheromone was also recorded: Cnephasia stephensiana (Doubleday, 1849), Epiblema cirsiana (Zeller, 1843), Pammene suspectana (Lienig \& Zeller, 1846), Argyresthia trifasciata (Staudinger, 1871), Oegoconia novimundi (Busck, 1915) and Yponomeuta malinellus (Zeller, 1838).

Adults of the species Noctua pronuba (Linnaeus, 1758) in the total number of 36 adults was recorded on Pandemis heparana pheromones from both companies. This species was also registered in traps with the Pandemis heparana pheromone by Hrdý et al. (1989) and Hrudová (2003). Furthermore, Yponomeuta malinellus was recorded on pheromones from both companies in the total number of 13 adults.

Various authors have already found a total of 58 non-target species flying on the Grapholita funebrana pheromone and 15 non-target species on the Pandemis heparana pheromone. The total spectrum of non-target species registered on pheromones for these two species is shown in Tab. III and IV.

\section{CONCLUSION}

The selectivity and efficiency of synthetic sex pheromones from Pherobank and Propher on fruit tree pests, Grapholita funebrana and Pandemis heparana, were tested, based on monitoring, with the following results:

1. Occurrence of Grapholita funebrana was confirmed in all studied localities, the highest number of captured individuals was in the orchard in Kyjov (2893 adults), and the lowest was in Soběšice (999 adults).

2. Occurrence of Pandemis heparana was shown in the locality of Kyjov, but only with a pheromone from Pherobank.

3. Pherobank pheromones proved to be more selective and effective than those from Propher during our experiment. More individuals of target species and fewer individuals of non-target species were captured on these pheromones than on pheromones from Propher.

4. Around 191 more specimens of non-target species flew on the pheromone from Propher than specimens of the target species.

5. A total of 2061 specimens from non-target moth species were captured.

6. The most abundant non-target species were Grapholita molesta, Cnephasia stephensiana and Argyresthia trifasciata. 
Acknowledgements

This paper was supported by Grant Agency No. AF-IGA2019-IP014. We are grateful to Z. Laštůvka for providing a revision of the determination of some of the tortricid specimens and for valuable advice and comments, similarly to both anonymous reviewers for important proposals and corrections.

\section{REFERENCES}

GILLIGAN, T. M., BAIXERAS, J. and BROWN, J. W. 2018. Online World Catalogue of the Tortricidae (ver. 4.0). Tordricid.net. [Online]. Available at: http://www.tortricidae.com/catalogue.asp [Accessed: 2020, July 13].

HLUCHÝ, Š. 2011. Non-target species of Tortricidae in pheromone traps in the protection of apple orchards, their flight dynamics and bionomy [in Czech: Necílové druhy obaleču (Tortricidae) ve feromonových lapácích v ochraně jabloňových sadů, jejich letová dynamika a bionomie]. Diploma thesis. Brno: Mendel University in Brno.

HRDÝ, I., KRAMPL, F., KULDOVÁ, J. et al. 1979a. Mapping of the Oriental Fruit Moth (Cydia molesta) by means of pheromone traps [in Czech: Mapování obaleče východního (Cydia molesta) feromonovými lapáky]. Ochrana rostlin, 15: 259-269.

HRDÝ, I., MAREK, J. and KRAMPL, F. 1979b. Sexual pheromone activity of 8-dodecenyl and 11-tetradecenyl acetates for males of several lepidopteran species in field trials. Acta Entomologica Bohemoslovaca, 76: 65-84.

HRDÝ, I., VRKOČ, J. and HOCHMUT, R. 1989. New records on sex attractants for males and faunistic comments on moths (Lepidoptera) from Czechoslovakia. Acta Entomologica Bohemoslovaca, 86(4): 252-268.

HRDÝ, I., MAREK, J., KRAMPL, F. et al. 1994. Distribution of the fruit tree pests Cydia molesta, Cydia funebrana and Anarsia lineatella (Lepidoptera: Tortricidae, Gelechiidae) in former Czechoslovakia as recorded by pheromone traps. Acta Societatis Zoologicae Bohemicae, 58(1-2): 53-60.

HRDÝ, I., KRAMPL, F., KULDOVÁ, J. and KALINOVÁ, B. 1997. Occurrence of potential orchard pests Cydia lobarzewskii and C. janthinana (Lepidoptera: Tortricidae) in the Czech Republic with notes on some other species according to pheromone trapping [in Czech: Výskyt potenciálních škůdců sadů, obaleče slivoňového, Cydia lobarzewskii a obaleče trnkového, $C$. janthinana (Lepidoptera: Tortricidae) v České republice a poznámky k dalším druhům podle úlovků do feromonových lapáků]. Klapalekiana, 33: 155-172.

HRUDOVÁ, E. 2003. The presence of non-target lepidopteran species in pheromone traps for fruit tortricid moths. Plant Protection Science, 39: 126-131.

HRUDOVÁ, E. 2005. Non-target lepidoptera species found in the feromone traps for selected tortricid species in 2002 and 2003 years. Acta Universitatis Agriculturae et Silviculturae Mendelianae Brunensis, 53(1): 35-44.

JAKUBÍKOVÁ, K. 2016. Evaluation of attractiveness of synthetic pheromones from different producers for selected Tortricidae species [in Czech: Zhodnocení atraktivity syntetických feromonů od různých výrobců pro vybrané druhy obalečů (Tortricidae)]. Diploma thesis. Brno: Mendel University in Brno.

JAKUBÍKOVÁ, K., KOMÍNKOVÁ, J., ŠEFROVÁ, H. and LAŠTŮVKA, Z. 2016. Target and Non-Target Moth Species Captured by Pheromone Traps for Some Fruit Tortricid Moths (Lepidoptera). Acta Universitatis Agriculturae et Silviculturae Mendelianae Brunensis, 64(5): 1561-1568.

KOMÍNKOVÁ, J. 2016. Efficacy of synthetic pheromones for leafrollers on the fruit trees and their attractiveness for nontarget species [in Czech: Účinnost syntetických feromonů na obaleče na ovocných dřevinách a jejich atraktivita pro necílové druhy]. Diploma thesis. Brno: Mendel University in Brno.

LAŠTU゚VKA, Z. and LIŠKA, J. 2011. Komentovaný seznam motýlů České republiky. Annotated checklist of moths and butterflies of the Czech Republic. Brno: Biocont Laboratory.

PRAŽANOVÁ, Ž. 2018. The reactions of target and non-target species to the pheromones of moths in the arboretum of the Mendel University in Brno [in Czech: Reakce cillových a necílových druhü na feromony motýli v arboretu Mendelovy univerzity v Brnè]. Diploma thesis. Brno: Mendel University in Brno.

RAZOWSKI, J. 2001. Die Tortriciden (Lepidoptera, Tortricidae) Mitteleuropas. Bestimmung - Verbreitung - Flugstandort - Lebensweise der Raupen. Bratislava: F. Slamka.

ROBINSON, G. S. 1976. The preparation of slides of Lepidoptera genitalia with special reference to the Microlepidoptera. Entomologist's Gazette, 27: 127-132.

SCOBLE M. J. 1995. The Lepidoptera. Form, function and diversity. London: The Natural History Museum.

SZIRÁKI, G. 1978. Examination on Tortricid moths trapped by synthetic attractans (Lepidoptera). Folia Entomologica Hungarica, 31(2): 259-264. 
ŠEFROVÁ, H. 2014. Pyraloidea and Tortricidae [in Czech: Zavíječi (Pyraloidea) a obaleči (Tortricidae)]. Listy cukrovarnické a řepařské, 130(9-10): 304-308.

VELCHEVA, N. 2000. Faunistichni belezhki vrchu vidovete listozavivachki, privlichani ot sintetichni pheromoni za slivov (Grapholita funebrana) i iztochen plodov chervey (G. molesta) [in Bulgarian: Faunal investigations on the species of leaf rollers attracted by synthetic pheromones intended for the plum (Grapholita funebrana) and oriental (G. molesta) fruit moths]. Plant Science, 37: 181-187.

Contact information

Žaneta Pražanová: xprazano@mendelu.cz 
